\title{
PENGEMBANGAN PERANGKAT PEMBELAJARAN IPS SMP BERBASIS MASALAH TEMA PERKEMBANGAN PESISIR PAITON UNTUK MENINGKATKAN HASIL BELAJAR SISWA
}

\author{
Fika Anjana \\ Tadris Ilmu Pengetahuan Sosial, Tarbiyah, Institut Ilmu Keislaman Zainul Hasan Genggong \\ FikaAnjana16@gmail.com
}

\begin{abstract}
Abstrak
Penelitian ini memiliki tujuan yaitu untuk menganalisis validitas pengembangan perangkat pembelajaran IPS SMP berbasis masalah dengan tema perkembangan kawasan Pesisir Paiton untuk meningkatkan hasil belajar siswa dan menganalisis keefektifan pengembangan perangkat pembelajaran IPS SMP berbasis masalah dengan tema perkembangan kawasan Pesisir Paiton untuk meningkatkan hasil belajar siswa. Jenis Penelitian ini ialah R \& D. Penelitian ini memiliki tiga tahap yang mengacu pada desain instruksional 4-D oleh Thiagarajan, Semmel, dan Semmel. Penelitian ini dilakukan untuk memperoleh produk perangkat pembelajaran yang akan divalidasi oleh tim ahli dan kemudian direvisi untuk mendapatkan perangkat pembelajaran yang valid, produk ini juga diuji cobakan di kelas untuk mengetahui keefektifan dari perangkat pembelajaran yang dikembangkan. Pengumpulan data penelitian ini diperoleh melalui observasi, tes, dan angket. Data hasil penelitian diperoleh sebagai berikut. Validitas perangkat pembelajaran yang meliputi hasil validasi RPP memiliki rata-rata 3.78 (kategori valid), hasil validasi Modul memiliki rata-rata 3.73 (kategori valid), hasil validasi LKS memiliki rata-rata 3.78 (kategori valid), hasil validasi alat evaluasi memiliki rata-rata 3.79 (kategori valid). Ketiga pelaksanaan pembelajaran mencapai rata-rata 3.44 (kategori sangat efektif). Hasil belajar kompetensi sikap spiritual memperoleh rata-rata 3.61 (kategori sangat baik dan sangat efektif), kompetensi sikap sosial memperoleh rata-rata sebesar 3.51 (kategori sangat baik dan sangat efektif), kompetensi pengetahuan memperoleh rata-rata 65.71 pada nilai pre test dan 84.6 pada nilai post test. Kompetensi keterampilan memperoleh rata-rata 2.76 (efektif) pada argumentasi invidu, dan 3.1 (sangat efektif) pada penugasan LKS, sedang penugasan Mind map memperoleh 3 (sangat efektif). Respon Siswa terhadap pembelajaran IPS dengan menggunakan model Pembelajaran Berbasis Masalah secara umum tergolong sangat positif. Berdasarkan hasil analisis data, maka dapat disimpulkan bahwa pengembangan perangkat pembelajaran IPS SMP berbasis masalah dengan tema perkembangan kawasan Pesisir Paiton memiliki tingkat validitas dan keefektifan yang baik untuk meningkatkan hasil belajar siswa SMPN 1 Paiton.

Kata Kunci: Model Pembelajaran Berbasis Masalah, Tema Perkembangan Kawasan Pesisir Paiton, Hasil Belajar Siswa.
\end{abstract}

\begin{abstract}
The goals of this study are (1) to analyze the validity of secondary school social science learning tool based on problem with theme the development of Paiton coastal area to improve student success learning (2) to analyze the effectiveness of secondary school social science learning tool based on problem with theme the development of Paiton coastal area to improve student success learning. The type of this study is $\mathrm{R} \& \mathrm{D}$, because it develops social learning tool based on problem with theme the development of Paiton coastal area. This study has three steps that according to Thiagarajan, Semmel, dan Semmel's 4-D instructional design. This steps are defining, designing, and developing. This study was conducted to obtained learning tool product that would be validated by the expert, and then it would be revised in order that would have a good quality, this product would be implemented at class to know the effectiveness of learning tool that had been developed. Data was collected by observation, test, and questionnaire. The result of this study shows that, the validity of learning tool that includes to lesson plan validity has mean score 3.78 (valid), the result of module validity has mean score 3.73 (valid), the result of student work sheet validity has mean score 3.78 (valid), the validity of evaluation instrument has mean score 3.79 (valid). The implementation of learning tool has mean score 3.44 (very effective). The result of success leaning on spiritual competence has mean score 3.61 (very good and effective), social competence has mean score 3.51 (very good
\end{abstract}


and affective), knowledge competence of pre test has mean score 65.7 and mean score of post test is 84.6. Skill competence has mean score 2.76 (effective) in individual argumentation, and mean score of student work sheet is 3.1 (very effective), whereas mean score of mind mapping task is 3 (very effective). Students respond toward social learning by using Problem Based learning model generally is very positive. Based on data analysis, it can be concluded that secondary school social science learning tool based on problem with theme the development of Paiton coastal area has good validity and effectiveness to improve student success learning in SMPN 1 Paiton.

Keyword: Problem Based Learning Model, The Development of Paiton Coastal Area Theme, Student Success Learning.

\section{PENDAHULUAN}

Sistem pendidikan menjadi bagian yang tak akan pernah terpisahkan dari kehidupan sosial budaya dan lingkungan sekitar. Pendidikan menurut Faturrahman (2012) merupakan setiap usaha, pengaruh, perlindungan, dan bantuan yang diberikan kepada anak tertuju kepada pendewasaan anak itu, atau lebih tepatnya untuk membantu anak agar cakap di dalam melaksanakan tugas hidupnya sendiri. Indonesia dibandingkan dengan negara ASEAN masih ketinggalan cukup jauh terutama dalam segi pendidikan, oleh karena itu berbagai upaya harus ditingkatkan agar Indonesia tidak menjadi tamu asing bagi negaranya sendiri dan lebih memanfaatkan potensi lingkungan yang ada dengan lebih baik.

Hal ini juga dikarenakan perangkat pembelajaran yang ada masih kurang dimanfaatkan, sehingga pelaksanaan proses belajar mengajar juga kurang optimal yang mengakibatkan mutu pendidikan yang kita harapkan belum lagi tecapai. Peningkatan mutu pendidikan dapat dilakukan dengan berbagai cara, salah satunya adalah dengan berusaha untuk memahami bagaimana peserta didik belajar dan bagaimana informasi yang diperoleh dapat di proses dalam pikiran mereka sehingga menjadi milik mereka serta bertahan lama dalam pikirannya. Dengan kata lain, perlu disadari bahwa peserta didik merupakan sumber daya manusia sebagai aset bangsa yang sangat berharga.

Menurut laporan Dirjen Dikdasmen Depdiknas (2008) dikemukakan bahwa salah satu masalah penting yang sering dihadapi guru dalam kegiatan pembelajaran adalah mengembangkan perangkat pembelajaran yang tepat dalam rangka membantu siswa mencapai kompetensi. Perangkat pembelajaran sebagai salah satu komponen penting dalam proses pembelajaran yang perlu dirancang sesuai dengan kebutuhan dan karakteristik siswa pada setiap satuan pendidikan. Setiap Perangkat pembelajaran akan dibuat berdasarkan pertimbangan-pertimbangan tertentu, yaitu mudah dipelajari siswa, sesuai dengan kemampuan siswa, ataupun praktis dan efisien.

Mata pelajaran yang dikembangkan di dalam perangkat pembelajaran ini ialah mata pelajaran IPS. Ilmu pengetahuan Sosial (IPS) di dalam dokumen kurikulum merupakan salah satu nama mata pelajaran yang diberikan pada jenjang sekolah dasar dan menengah. Menurut Sapriya (2009), IPS merupakan sebuah nama mata pelajaran yang integrasi dari cabang ilmu sejarah, ekonomi, geografi, dan sejarah.

Saat ini pendidikan di Indonesia masih didominasi oleh kelas yang berfokus pada guru sebagai sumber informasi utama (pembelajaran konvensional) dan kurang memanfaatkan lingkungan siswa sebagai sumber belajar. Akibatnya pemahaman siswa terhadap materi ajar seringkali belum sesuai harapan dan tujuan dari pembelajaran yang ingin dicapai, hal ini secara garis besar dikarenakan oleh tiga hal yaitu: (1) banyak siswa mampu menyajikan tingkat hafalan yang baik terhadap materi ajar yang diterimanya, tetapi pada kenyataannya mereka tidak memahaminya, (2) sebagian besar siswa tidak mampu menghubungkan antara apa yang mereka pelajari dengan bagaimana pengetahuan tersebut akan dipergunakan/dimanfaatkan, dan (3) siswa memiliki kesulitan untuk memahami konsep akademik sebagaimana mereka biasa 
diajarkan yaitu dengan menggunakan sesuatu yang abstrak dan metode ceramah.

Metode ceramah yang sering dipakai dalam pembelajaran konvensional cenderung membuat para siswa belajar konsep-konsep secara abstrak, belajar konsep-konsep tanpa melalui proses penggunaan konsep-konsep tersebut, atau belajar konsep-konsep tanpa mengalami acuan konkrit konsep-konsep. Belajar yang demikian cenderung bersifat menerima pengetahuan dan bukan membangun sendiri pengetahuan. Dominasi guru terhadap pembelajaran, akan membuat siswa pasif dan kehilangan kesempatan untuk mengeksplorasi pengetahuan yang ingin didapat dan diberikan dalam proses pembelajaran di kelas. Untuk itu diperlukan suatu model pembelajaran yang dapat memberdayakan siswa.

Peneliti menggunakan tema perkembangan kawasan Pesisir Paiton di dalam model pembelajaran berbasis masalah.Tema tersebut dipilih karena mempertimbangkan beberapa hal, yaitu: Pertama, relevan dengan kebutuhan siswa terkait dengan karakteristik siswa yang berbeda menurut sosial budaya, aspirasi politik, dan kondisi ekonomi. Kedua, terdapat beberapa potensi yang ada di kawasan tersebut yang patut diketahui dan dimanfaatkan dengan baik. Ketiga, untuk menjembatani keterbatasan kemampuan daya serap dan keterbatasan kemampuan guru dalam proses pembelajaran di kelas .

Penelitian ini menyesuaikan kurikulum yang ada di sekolah, adapun kurikulum yang digunakan di sekolah tersebut ialah kurikulum 2013. Menurut Suryanti (2008), kurikulum 2013 menekankan pada dimensi pedagogik modern dalam pembelajaran, yaitu menggunakan pendekatan ilmiah. Proses pembelajaran menyentuh tiga ranah, yaitu sikap, pengetahuan, dan keterampilan. Peneliti menggunakan tema perkembangan kawasan Pesisir Paiton yang ada di kabupaten Probolinggo dalam perangkat pembelajaran IPS. Hal ini diharapkan dapat meningkatkan hasil belajar siswa.

Implementasi model desain sistem pembelajaran ini memerlukan proses yang sistematis dan menyeluruh. Hal ini diperlukan untuk dapat menciptakan desain sistem pembelajaran yang mampu digunakan secara optimal dalam mengatasi masalah-masalah pembelajaran. Sehingga penelitian ini mengkaji tentang pengembangan perangkat pembelajaran IPS SMP berbasis masalah dengan tema perkembangan kawasan Pesisir Paiton untuk meningkatkan hasil belajar siswa. Penelitian yang dilakukan ini bertujuan (1) menganalisis validitas pengembangan perangkat pembelajaran IPS SMP berbasis masalah dengan tema perkembangan kawasan Pesisir Paiton untuk meningkatkan hasil belajar siswa (2) menganalisis keefektifan pengembangan perangkat pembelajaran IPS SMP berbasis masalah dengan tema perkembangan kawasan Pesisir Paiton untuk meningkatkan hasil belajar siswa

\section{METODE}

Pada dasarnya bagian ini menjelaskan bagaimana penelitian itu dilakukan. Materi pokok bagian ini adalah: (1) rancangan penelitian; (2) populasi dan sampel (sasaran penelitian); (3) teknik pengumpulan data dan pengembangan instrumen; (4) dan teknik analisis data. Untuk penelitian yang menggunakan alat dan bahan, perlu dituliskan spesifikasi alat dan bahannya. Spesifikasi alat menggambarkan kecanggihan alat yang digunakan sedangkan spesifikasi bahan menggambarkan macam bahan yang digunakan.

Penelitian yang dilakukan ini merupakan penelitian pengembangan (Research and Development), karena mengembangkan perangkat pembelajaran IPS SMP berbasis masalah dengan tema perkembangan kawasan Pesisir Paiton. Penelitian ini dilakukan untuk memperoleh produk perangkat pembelajaran yang akan divalidasi oleh tim ahli, kemudian diuji cobakan di kelas. Adapun model pengembangan perangkat pembelajaran yang dipakai di dalam penelitian ini mengacu pada model 4-D oleh Thiagarajan, Semmel, dan Semmel.

Model ini terdiri dari empat tahap pengembangan yaitu Define, Design, Develop, dan Disseminate atau diadaptasikan menjadi model 4-P, yaitu pendefinisian, perancangan, pengembangan, 
dan penyebaran (Trianto, 2009). Berhubungan dengan keterbatasan waktu dan biaya dimiliki, sehingga desain instruksional yang ada di dalam penelitian ini hanya meliputi tahap pendefinisian, perancangan, dan pengembangan.

Adapun Subyek Penelitian ini ialah terdiri dari guru dan siswa di dalam tahap pendefinisian, serta validator dan siswa di dalam tahap pengembangan. Menurut Iqbal (2002), pengumpulan data adalah pencatatan peristiwa-perisriwa atau hal-hal atau keterangan-keterangan atau karakteristik-karakteristik sebagian atau seluruh elemen populasi yang akan menunjang atau pendukung penelitian. Teknik pengumpulan data di dalam penelitian ini ialah melalui observasi, kerja mandiri, validasi, metode tes, dan angket.

Data yang telah diperoleh dalam penelitian ini dianalisis secara deskriptif untuk mengetahui validitas dan keefektifan dari perangkat pembelajaran yang dikembangkan. Analisis data dilakukan dengan cara validitas perangkat pembelajaran IPS untuk mengetahui validitas perangkat yang dikembangkan. Sedangkan untuk mengetahui keefektifan perangkat pembelajaran yang terdiri dari keterlaksanaan pembelajaran ialah menggunakan pedoman observasi dengan rumus

$N=\frac{\sum \text { skor yang diperoleh }}{\text { skor total }}$

Analisis respon siswa menggunakan angket dengan rumus

Nilai $=\frac{\text { Jumlah respon siswa }}{\text { jumlah seluruh siswa }} \times 100$

Adapun analisis hasil belajar siswa yang terdiri dari kompetensi sikap menggunakan rumus

Skor akhir $=\frac{\text { shor diperoleh }}{\text { skor maksimal }} \times 4$

Sedangkan kompetensi pengetahuan, maka dianalisis melalui SPSS 16.0, dengan uji normalitas, homogenitas, dan uji-t. Kompetensi keterampilan ini dapat dilihat melalui instrument daftar cek (checklist)

\section{HASIL DAN PEMBAHASAN}

Tahap pertama yang dilakukan dalam pengembangan perangkat pembelajaran yaitu menenentukan mata pelajaran untuk menjadi objek pengembangan, sehingga mata pelajaran IPS SMP kelas VII semester genap merupakan objek pengembangan perangkat pembelajaran.

Berdasarkan hasil observasi di SMPN 1 Paiton terkait pembelajaran IPS di kelas yaitu diperoleh data bahwa perangkat pembelajaran IPS di SMPN 1 Paiton masih banyak yang harus diperbaiki, yaitu hampir dari seluruh kegiatan yang ada di RPP belum menggunakan model pembelajaran berbasis masalah, metode yang digunakan masih belum mengarahkan pada pembelajaran kelompok, hal ini terlihat dari beberapa kegiatan pembelajaran yang dilaksanakan secara individu. Kurang lengkapnya sarana prasarana seperti multimedia di dalam pembelajaran IPS akan membuat siswa mudah bosan dalam pembelajaran, oleh karena itu dibutuhkan kreativitas guru di dalam merencanakan pelaksanaan pembelajaran IPS.

Penggunaan bahan ajar di SMPN 1 Paiton kurang maksimal, hal ini terlihat dari belum adanya LKS yang menyajikan permasalahan sosial dan kontekstual sesuai dengan kehidupan siswa sehari-hari. Selama ini pembelajaran IPS di dalam kelas cenderung pada teacher center, hal ini terlihat dari proses kegiatan belajar mengajar yang hanya mencatat dan mendengarkan penjelasan guru.

Apabila dilihat dari analisis karakteristik siswa di SMPN 1 Paiton menenjukkan bahwa kurangnya motivasi siswa dalam belajar, hal ini terlihat dari sedikitnya siswa untuk bertanya dan menjawab terkait materi yang dipelajari, sehingga tidak ada peningkatan siswa di dalam mengajukan dan menjawab pertanyaan terkait materi yang belum dipahami. Kurangnya ketertarikan dan motivasi siswa dalam pembelajaran IPS diakibatkan oleh adanya paradigm yang dimiliki siswa bahwa pembelajara IPS bersifat menghafal, sehingga hal ini merupakan factor yang menghambat 
keaktivan siswa di dalam menyempaikan argumentasi.

Apabila dilihat dari kreativitas siswa, tidak jarang dari siswa yang kurang mandiri di dalam mengerjakan tugas dari guru, contohnya ialah tugas pembuatan peta yang diperintahkan oleh guru, tidak banyak dari siswa masih perlu bimbingan khusus dari guru agar pembuatan peta dapat terlaksana. Hal ini disebabkan oleh faktor pendekatan teacher center yang diterapkan oleh guru di dalam pembelajaran IPS yang telah mengurangi kreativitas dan sifat mandiri siswa. Pendekatan teacher center membuat siswa hanya sebagai pendengar dan menjadi pasif. Disamping itu guru sangat jarang sekali menghubungkan pembelajaran IPS dengan kehidupan nyata siswa, sehingga menimbulkan pembelajaran yang kurang bermakna.

Berdasarkan latar belakang siswa di SMPN 1 Paiton, sebagian besar siswa berasal dari kalangan menengah kebawah, hal ini terbukti dari penuturan wali kelasnya dimana sebagian wali murid berprofesi sebagai nelayan di peringkat pertama, berprofesi sebagai petani di peringkat kedua, dan buruh pabrik rokok gudang garam dan sampoerna di peringkat ketiga.

Berdasarkan observasi pada hasil belajar siswa, maka diperoleh data bahwa hasil akademik siswa tergolong masih rendah, hal ini terbukti dari hasil nilai Ulangan harian, UTS, UAS semester ganjil dan genap. Berikut merupakan data hasil belajar siswa kelas VII C SMPN 1 Paiton.

Tabel 1 Hasil Belajar Siswa SMPN 1 Paiton

\begin{tabular}{|c|c|c|c|}
\hline \multirow{2}{*}{$\begin{array}{c}\text { Contoh } \\
\text { Kelas }\end{array}$} & \multicolumn{3}{|c|}{ Rata-Rata Hasil Belajar Siswa } \\
\cline { 2 - 4 } & $\begin{array}{c}\text { Ulangan } \\
\text { Harian }\end{array}$ & UTS & UAS \\
\hline \multirow{3}{*}{$\begin{array}{c}\text { Kelas } \\
\text { VII C }\end{array}$} & $\begin{array}{c}26 \text { siswa } \\
\text { remidi }\end{array}$ & $\begin{array}{c}20 \text { siswa } \\
\text { remidi }\end{array}$ & $\begin{array}{c}8 \text { siswa } \\
\text { remidi }\end{array}$ \\
\cline { 2 - 4 }
\end{tabular}

(Sumber: Hasil pengolahan data)

Peneliti menggunakan kelas VII C sebagai contoh subjek penelitian di dalam memaparkan data terkait hasil belajar siswa karena kelas tersebut merupakan kelas unggulan.

Berdasarkan hasil wawancara lisan dengan guru bidang studi IPS SMPN 1
Paiton dan beberapa siswa yang telah mempelajari mata pelajaran IPS terpadu diperoleh data bahwa pemberian tugas kepada siswa belum memberikan pengalaman yang bermakna bagi siswa, karena pemberian tugas dari guru hanya berpacu dalam LKS yang berisi soal-soal terkait materi saja, pemberian tugas kepada siswa belum memberikan pengelaman belajar yang dapat menyelesaikan permasalahan sosial yang kontekstual. Sehingga disini peneliti menyiapkan Lembar Kegiatan Siswa yang disesuaikan dengan kondisi dan lingkungan siswa. Pada kegiatan analisis konsep diperoleh data bahwa konsep yang diberikan kepada siswa diperoleh dari LKS siswa, dimana LKS tersebut hanya berisi sebagian materi, sehingga konsep yang diberikan kurang mengarahkan siswa pada pembelajaran yang kontekstual.

Tes acuan patokan di dalam penelitian ini menggunakan bentuk tes tertulis yang berupa butir soal dan lembar pengamatan kegiatan siswa. Hasil belajar sikap spiritual, sosial, dan keterampilan, menggunakan tes non tertulis berupa lembar observasi. Penyusunan tes hasil belajar disesuaikan dengan KI dan KD yang akan dicapai oleh siswa. Apabila dilihat dari pemilihan media melalui kegiatan observasi, maka diperoleh keterangan bahwa sarana dan prasaran yang dimiliki oleh SMPN 1 paiton masih tergolong kurang lengkap, hal ini terbukti dari tidak adanya LCD dan jaringan internet yang mudah diakses untuk setiap kelas. Namun dari segi koleksi buku, SMPN 1 Paiton memiliki berbagai koleksi buku. Berdasarkan observasi tersebut, maka diperlukan pemanfaatan media sebagai sarana untuk mencapai target pembelajaran.

Berdasarkan hasil pemilihan media maka diperoleh keputusan bahwa, peneliti menggunakan beberapa media untuk menunjang proses pembelajaran. Pertama, menyusun modul untuk menunjang materi pembelajaran yang berbasis masalah dan kontekstual. Kedua, LKS sebagai media untuk menunjang proses pembelajaran dengan menggunakan model pembelajaran berbasis masalah. Media ini disusun untuk menumbuhkan hasil belajar siswa dalam pembelajaran IPS. Sumber belajar yang 
dikembangkan yaitu Rencana Pelaksanaan Pembelajaran, modul, LKS, serta alat evaluasi (THB) sebagai pendukung dalam kegiatan pembelajaran.

Validasi dilakukan pada perangkat pembelajaran IPS, yang meliputi RPP, Modul, LKS, dan alat evaluasi (pre test dan post test). Validasi ini bertujuan sebagai evaluasi dan saran yang harus diperbaiki untuk mendapatkan kualitas perangkat pembelajaran yang dikembangkan menjadi lebih baik dan efektif untuk digunakan di dalam kegiatan pembelajaran IPS. Adapun aspek yang dinilai di dalam validitas perangkat pembelajaran meliputi, identitas perangkat, isi, konstruksi, dan bahasa. Hasil dari validasi yang berupa perbaikan, kritik, dan saran dari validator dijadikan masukan yang digunakan sebagai dasar revisi dan penyempurnaan perangkat pembelajaran. Terdapat dua validator yang menilai perangkat yang dikembangkan di dalam penelitian ini. Tahap Validasi dan revisi akan menghasilkan validitas perangkat pembelajaran yang lebih baik.

Uji coba perangkat pembelajaran yang telah divalidasi dan revisi di dalam kelas ini bertujuan untuk mengetahui keefektifan perangkat pembelajaran, sehingga di dalam uji coba ini akan membahas mengenai keterlaksanaan perangkat pembelajaran, respon siswa dan hasil belajar siswa. Ketiga bahasan tersebut didukung dengan instrument lembar observasi keterlaksanaan pembelajaran, instrument angket respon siswa terhadap proses pembelajaran IPS, dan instrument lembar observasi dan tes hasil belajar siswa. Uji coba perangkat ini akan menghasilkan keefektifan perangkat pembelajaran di dalam kelas.

Menurut penilaian validator terhadap RPP yang dikembangkan oleh peneliti diperoleh bahwa RPP tergolong valid dan sangat valid. Nilai rata-rata dari seluruh nilai yang diperoleh dari validator pertama dan kedua ialah sebanyak 3.78 dengan kategori valid. Kedua validator menyimpulkan bahwa RPP yang dikembangkan oleh peneliti berkategori valid dan dapat digunakan dengan sedikit revisi.

Modul dibuat sebagai bahan ajar siswa dalam pembelajaran serta panduan di dalam memahami konsep. Modul dikembangkan oleh peneliti dengan tujuan untuk meningkatkan pengetahuan dan pemahaman siswa mengenai materi IPS dengan tema perkembangan kawasan pesisir Paiton, dimana tema ini dikaitkan dengan Sumber Daya Alam di dalam materi IPS kelas VII. Pemilihan tema ini disesuaikan dengan kondisi dan karakter siswa, sehingga tema ini juga sangat sesuai dengan model pembelajaran berbasis masalah di dalam kurikulum 2013.

Menurut penilaian validator terhadap modul yang dikembangkan oleh peneliti diperoleh bahwa nilai rata-rata dari seluruh nilai yang diperoleh dari validator pertama dan kedua ialah sebanyak 3.73 dengan kategori valid. Kedua validator menyimpulkan bahwa modul yang dikembangkan oleh peneliti berkategori valid dan dapat digunakan dengan sedikit revisi.

LKS dibuat sebagai bahan ajar yang memudahkan peserta didik untuk berinteraksi dengan materi yang diberikan, serta LKS juga menyajikan tugas-tugas yang meningkatkan penguasaan peserta didik terhadap materi yang diberikan yang memuat instruksi yang harus dilakukan oleh siswa, LKS yang dibuat oleh peneliti ini juga berguna untuk menilai sikap sosial dan kompetensi keterampilan siswa. Siswa akan diberikan LKS pada pertemuan pertama.

Menurut penilaian validator terhadap LKS yang dikembangkan oleh peneliti diperoleh bahwa nilai rata-rata dari seluruh nilai yang diperoleh dari validator pertama dan kedua ialah sebanyak 3.78 dengan kategori valid. Kedua validator menyimpulkan bahwa LKS yang dikembangkan oleh peneliti berkategori valid dan dapat digunakan dengan sedikit revisi.

Alat evaluasi dibuat untuk mengetahui perubahan yang terjadi di dalam diri siswa dan menggambarkan adanya peningkatan hasil belajar pada diri siswa sesuai dengan kriteria yang telah ditetapkan, alat evaluasi ini berupa soal pre test dan post test. Menurut penilaian validator terhadap alat evaluasi pre test dan post test yang dikembangkan oleh peneliti diperoleh bahwa nilai rata-rata dari seluruh nilai yang 
diperoleh dari validator pertama dan kedua ialah sebanyak 3.79 dengan kategori valid. Kedua validator menyimpulkan bahwa alat evaluasi yang dikembangkan oleh peneliti berkategori valid dan dapat digunakan dengan sedikit revisi.

Butir soal juga dilakukan uji validasi dan reliabilitas yang telah dilakukan secara kuantitatif. Uji validasi dan reliabelitas soal dilakukan menggunakan bantuan SPSS 16.0. Soal-soal yang disusun ialah pada soal pre test dan post test dengan jumlah siswa sebanyak 27 siswa. Melalui uji validasi dan reliabilitas ini, maka soal yang berkategori valid yang digunakan sebagai alat evaluasi dalam penelitian ini. Sedangkan untuk soal yang berkategori tidak valid maka soal tersebut akan berstatus drop atau dibuang.

Hasil perhitungan validasi dan reliabilitas mengacu pada butir soal yang disusun. Berdasarkan hasil uji validasi soal pre test diperoleh 20 soal valid pada soal pilihan ganda dengan jumlah keseluruhan soal pilihan ganda sebanyak 20 soal, sedang 5 soal valid pada soal uraian dengan jumlah keseluruhan soal uraian sebanyak 10 soal, sehingga sisa 5 soal uraian berstatus tidak valid.

Berdasarkan Uji reliabilitas dengan menggunakan uji reliability analysis pada butir soal yang serupa, maka hasil dari uji reliabilitas menggunakan SPSS 16.0 menunjukkan bahwa Cronbach's Alpha diperoleh nilai 0.802 yang berarti nilai ini ditafsirkan dengan kriteria 0.800-1000 dengan tingkat reliabilitas sangat tinggi. Hasil ini menunjukkan bahwa butir soal pilihan ganda berkategori reliable dengan tafsiran kriteria sangat tinggi dan dapat digunakan sebagai alat evaluasi di dalam penelitian.

Sedang uji reliabilitas menggunakan SPSS 16.0 pada butir soal uraian diperoleh data bahwa Cronbach's Alpha diperoleh nilai 0.296 yang berarti nilai ini ditafsirkan dengan kriteria 0.200-0.399 dengan tingkat reliabilitas rendah. Hasil ini menunjukkan bahwa butir soal uraian berkategori reliable dengan tafsiran kriteria rendah dan dapat digunakan sebagai alat evaluasi di dalam penelitian.

Disamping itu peneliti juga menguji cobakan perangkat di dalam kelas untuk mengetahui keefektifan dari pada perangkat tersebut. Keterlaksanaan pembelajaran dengan menerapkan perangkat pembelajaran IPS tema perkembangan kawasan pesisir Paiton dengan menggunakan model PBL terhadap kelas VII C SMPN 1 Paiton ini diamati oleh seorang pengamat dengan menggunakan lembar observasi keterlaksanaan pembelajaran.

Adapun keefektifan perangkat pembelajaran setelah dilakukannya uji coba perangkat di kelas terkait keterlaksanaan pembelajaran, maka diperoleh data bahwa pengamat memberikan penilaian kategori terlaksana dan sangat terlaksana pada keterlaksanaan pembelajaran selama menggunakan perangkat pembelajaran yang dikembangkan oleh peneliti. Dari penilaian pengamat diperoleh nilai rata-rata sebanyak 3.29 dengan kategori terlaksana. Sedang keterlaksanaan pembelajaran pada pertemuan kedua dan ketiga, pengamat memberikan nilai hampir sama dengan pertemuan pertama, yaitu pertemuan kedua nilai rata-rata sebanyak 3.48 dengan kategori Terlaksana, dan pertemuan ketiga medapati nilai rata-rata sebanyak 3.56 dengan kategori Terlaksana. Berdasarkan data tersebut dapat dinyatakan bahwa kegiatan pembelajaran terlaksana dengan baik. Sehingga ketiga hasil nilai rata-rata hasil observasi keterlaksanaan pembelajaran memiliki kriteria sangat efektif.

Selain dengan cara melihat keterlaksanaan perangkat di dalam pembelajaran IPS, maka untuk mengetahui keefektifan perangkat yang dikembangkan juga dapat dilihat dari hasil belajar siswa. Hasil belajar siswa dapat ditunjukkan dengan hasil penilaian sikap spiritual, sikap sosial, keterampilan dan pengetahuan.

Peneliti menggunakan lembar pengamatan dan penilaian untuk menilai sikap spiritual siswa. Penilaian sikap spiritual siswa mengacu pada indikator sikap spiritual yang terlampir di dalam Rencana Pelaksanaan Pembelajaran (RPP). Indikator yang dijadikan acuan penilaian yaitu membaca doa sebelum dan setelah pelaksanaan pembelajaran serta memberi dan menjawab salam. Hasil belajar IPS ranah sikap spiritual berdasarkan pengamatan diperoleh data bahwa hasil 
penilaian mengalami peningkatan di setiap pertemuan.

$\begin{array}{rrrr}\text { Nilai } & \begin{array}{r}\text { Rata-rata } \\ \text { sebelum }\end{array} & \begin{array}{r}\text { pada } \\ \text { dan }\end{array} & \begin{array}{r}\text { indikator } \\ \text { sesudah }\end{array}\end{array}$ pembelajaran mendapatkan nilai 3.7 dengan kategori sangat baik dan memiliki kriteria sangat efektif, sedang nilai rata-rata pada indikator memberi dan menjawab salam mendapatkan nilai 3.53 dengan kategori baik dan memiliki kriteria sangat efektif.

Nilai hasil belajar kompetensi sikap spiritual pada pertemuan pertama di dalam indikator membaca doa sebelum dan setelah pembelajaran memperoleh nilai 3.4, sedang pada indikator memberi dan menjawab salam pada pertemuan pertama mendapatkan nilai 3.2. Nilai hasil belajar sikap spiritual pada pertemuan kedua untuk indikator membaca doa sebelum dan setelah pembelajaran memperoleh nilai 3.8, sedang nilai hasil belajar sikap spiritual pada indikator memberi dan menjawab salam memperoleh nilai 3.6. Nilai hasil belajar sikap spiritual pada pertemuan ketiga untuk indikator membaca doa sebelum dan setelah pembelajaran memperoleh nilai 3.9, sedang sedang nilai hasil belajar sikap spiritual pada indikator memberi dan menjawab salam memperoleh nilai 3.5.

Peneliti juga menggunakan lembar pengamatan dan penilaian untuk menilai sikap sosial siswa. Penilaian sikap sosial siswa mengacu pada indikator sikap sosial yang terlampir di dalam Rencana Pelaksanaan Pembelajaran (RPP). Indikator yang dijadikan acuan penilaian yaitu Jujur, displin, tanggung jawab, dan percaya diri. Berdasarkan pengamatan dan penilaian yang dilakukan maka memperoleh data nilai hasil observasi sikap jujur pada kelima kelompok mendapatkan nilai rata-rata sebesar 3.6 dengan kategori sangat baik dan memiliki kriteria sangat efektif. Nilai hasil observasi sikap disiplin pada kelima kelompok memperoleh nilai rata-rata sebesar 3.74 dengan kategori sangat baik dan memiliki kriteria sangat efektif. Nilai hasil observasi sikap tanggung jawab pada kelima kelompok memperoleh nilai rata-rata sebesar 3.4 dengan kategori sangat baik dan memiliki kriteria sangat efektif. Nilai hasil observasi sikap percaya diri pada kelima kelompok memperoleh nilai rata-rata sebesar 3.33 dengan kategori sangat baik dan memiliki kriteria sangat efektif.

Kompetensi pengetahuan dapat diketahui melalui hasil penilaian pre test dan post test yang terdiri dari soal pilihan ganda dan uraian. Adapun hasil pre test dan post test yang telah dicapai siswa menunjukkan bahwa kondisi awal tingkat kompetensi pengetahuan siswa pada soal pre test dikategorikan rendah. Hal ini terlihat dari rata-rata nilai pre test sebesar 65.71 yang berbanding terbalik dengan ratarata pada nilai post test sebesar 84.6. Terdapat 23 siswa yang tidak tuntas pada kegaiatan pre test, atau apabila dipersentasekan menjadi $14 \%$, hasil nilai rata-rata tersebut masih jauh dari nilai ratarata ideal. Namun, disisi lain terdapat 24 siswa yang tuntas dalam kegiatan post test atau apabila dipersentasekan sebesar 89\%, hal ini berbanding terbalik dengan nilai pre test, sehingga hal ini mengalami peningkatan.

Untuk mengetahui tingkat korelasi antara hasil pre test dan post test perlu diketahui terlebih dahulu nilai uji normalitas (distribusi) dan homogenitas menggunakan spss 16.0. Uji normalitas ini berfungsi untuk mengetahui apakah data yang diperoleh memiliki distribusi normal. Uji normalitas data ini menggunakan pendekatan Kolmogorov-smirnov dengan ketentuan bahwa apabila probabilitas ata Asymp. Sig (2 tailled) lebih besar dari level of significanct (5\%), maka data distribusi normal.

Hasil dari perhitungan data uji normalitas diperoleh angka probabilitas atau asym.sig (2 tailed). Baik pre test maupun post test jika dibandingkan dengan taraf signifikansi 5\% (0.05) menunjukkan bahwa untuk data pre test sebesar $0.079>0.05$ dan nilai post test sebesar $0.657>0.05$. Hasil ini menunjukkan bahwa data pre test dan post test memiliki distribusi normal yang artinya data berasal dari populasi berdistribusi normal.

Disamping itu hasil data uji homogenitas menunjukkan bahwa sig (2 tailed) diperoleh nilai 0.225 yang berarti lebih besar dari pada taraf signifikansi 0.05. Hasil ini menunjukkan bahwa data tingkat hasil belajar siswa pre test dan post test 
tersebut telah menunjukkan data yang homogen.

Hasil Uji-T rata-rata melalui Paired defferences antara hasil belajar siswa pada uji pre test dan post test dapat diketahui nilai $\mathrm{T}$ hitung sebesar -7.211. Nilai $\mathrm{T}$ Hitung ini jika dibandingkan dengan nilai Ttabel dengan df 26 dan taraf signifikansi 5\%, maka diperoleh T-tabel sebesar 0.388 . Dengan demikian nilai T-hitung > T-tabel sehingga H1 diterima. Artinya, ada perbedaan pengaruh antara sebelum dan setelah dilaksanakan pembelajaran IPS berbasiskan pemecahan masalah dengan tema perkembangan kawasan Pesisir Paiton di kelas VII SMPN 1 Paiton.

Selanjutnya, hasil data pada kolom sig.(2-tailed) juga menunjukkan bahwa nilai $\mathrm{P}$-value < Level of significanct (5\%) artinya diterima $\mathrm{Ha}$ yang menunjukkan ada hubungan significant peningkatan hasil belajar siswa antara hasil pre test dan post test.

Kompetensi keterampilan dapat diketahui melalui observasi dan penilaian kompetensi keterampilan yang terdiri dari tes praktik yaitu melalui argumentasi lisan dan portofolio yaitu melalui LKS (Lembar Kerja Siswa) dan penugasan Mind Map. Tes praktik dapat dinilai melalui argumentasi lisan oleh masing-masing siswa mengenai tanggapan terkait artikel yang tertera di dalam LKS.

Untuk mengetahui keefektifan perangkat pembelajaran yang dikembangkan juga melalui respon siswa terhadap pembelajaran dengan menggunakan model PBL. Berdasarkan hasil angket maka diperoleh data bahwa respon siswa terhadap pembelajaran IPS secara umum dikategorikan baik. Data menunjukkan bahwa siswa sangat setuju dan setuju dengan pernyataan bahwa guru

\section{DAFTAR PUSTAKA}

Arikunto, Suharsimi. (2010). Prosedur penelitian suatu pendekatan praktik. Yogyakarta: Rineka Cipta.

Dwi Nur Heni, dkk. (2015). Pengembangan perangkat pembelajaran tematik bervisi SETS berkarakter peduli mengajarkan model pembelajaran berbasis masalah ini dengan jelas dan mudah dipahami. Siswa juga sangat setuju dengan diterapkannya model pembelajaran berbasis masalah, karena hal ini dapat membantu mereka memahami materi pembelajaran. Disamping itu, siswa juga sangat menyetujui adanya modul dan LKS yang mudah dipahami yang digunakan di dalam pembelajaran. Pembelajaran yang telah dilakukan dapat mengembangkan pengetahuan yang diperoleh di luar sekolah, hal ini terbukti dari jumlah persentase siswa yang sangat tinggi dalam memilih jawaban sangat setuju.

\section{SIMPULAN}

Berdasarkan analisis hasil penelitian, maka diperoleh kesimpulan bahwa: (1) validitas perangkat pembelajaran berdasarkan hasil validasi RPP, maka diperoleh kategori valid. Validasi modul diperoleh kategori valid. Validasi LKS diperoleh kategori valid. Validasi alat evaluasi diperoleh kategori valid. Berdasarkan hasil validasi tersebut, maka dapat disimpulkan perangkat yang dikembangkan oleh peneliti berkategori valid dan dapat digunakan dengan sedikit revisi, sehingga perangkat pembelajaran dapat diterapkan pada pembelajaran IPS di SMPN 1 Paiton. (2) keefektifan perangkat pembelajaran berdasarkan keterlaksanaan pembelajaran IPS menggunakan perangkat yang dikembangkan oleh peneliti tergolong sangat efektif. Perangkat pembelajaran yang digunakan sangat efektif untuk meningkatkan sikap spiritual, sosial, pengetahuan, dan keterampilan siswa. Sedang respon siswa terhadap perangkat pembelajaran yang dikembangkan secara umum tergolong sangat baik dan efektif.

lingkungan. Journal of Primary education. 4 (1), 30-35.

Elaine. (2015). Pengembangan perangkat pembelajaran berbasis lingkungan sekitar terhadap siswa migran di Ghana. Journal of Education and Learning. 4 (2), 6-18. 
Ibrahim, Muslimin. (2012). Pembelajaran Berdasarkan Masalah Edisi Dua. Unesa University Press.

Javed, Muhammad. (2013). Pengembangan perangkat pembelajara berupa modul untuk meningkatkan kemampuan membaca siswa pada sekolah tingkat menengah Malaysia. International Journal of Instruction. 8 (2), 139- 154.

Khumaidah, Umi. (2015). Pengembangan Perangkat Pembelajaran Tema Lingkungan Dengan Model Kooperatif Tipe Teams Games Tournament. Journal Of Primary Education. 4 (1), 71-76.

Lestari, Ika. (2013). Pengembangan bahan ajar berbasis kompetensi. Jakarta: academia.

Prastowo, Andi. (2011). Panduan kreatif membuat bahan ajar inofatif :Menciptakan metode pembelajaran yang menarik dan menyenangkan. Yogyakarta: DIVA press.

Sitiatava Rizema Putra. (2012). Desain evaluasi belajar berbasis kinerja. Yogyakarta: Diva Press.

Slavin, Robert E. (2011). Psikologi Pendidikan: Teori dan praktik. Jakarta: PT Indeks.

Sri Hadi Nugraheni. (2014). Pengembangan perangkat pembelajaran Ilmu Pengetahuan Sosial (IPS) SMP berbasis situs sejarah lokal. Journal of educational social studies. 3 (2), 5155.

Sutrisno, Slamet. (2013). Pengembangan perangkat pembelajaran mata pelajaran IPS kelas VIII SMP dengan menerapkan model pembelajaran kooperatif tipe STAD. Interaksi, 1 (1), $1-17$. 